\title{
ANTYWARTOŚCI. KONCEPTUALIZACJA ZŁA W ŚWIADOMOŚCI JĘZYKOWEJ POLAKÓW I ROSJAN
}

\author{
ANTI-VALUES. THE CONCEPT OF EVIL IN THE POLISH \\ AND RUSSIAN LANGUAGE CONSCIOUSNESS
}

\section{BARBARA RODZIEWICZ}

\begin{abstract}
AвSTRACт. The present article is an attempt at establishing a way of understanding the term evil as well as characterizing all the phenomena the term encompasses in communities of Polish and Russian students. The author analyses the results of a Free Word Association Test on the material of associative dictionaries.
\end{abstract}

Keywords: anti-values, evil, associative experiment, language consciousness, Poles and Russians

Barbara Rodziewicz, Uniwersytet Szczeciński, Szczecin - Polska, rodziew@vp.pl

ORCID ID: 0000-0001-7724-5602

Zło jest fenomenem specyficznie ludzkim [...]. Zło jest jednak nie tylko ludzkie, zło jest tragiczne.

Erich Fromm

Przeglądając różne publikacje z zakresu szeroko pojmowanej lingwistyki antropologicznej, z zaskoczeniem czy nawet rozczarowaniem zaobserwowałam, iż badania i studia nad antywartościami są wśród nich niewystarczające, wręcz deficytowe. O ile wartości stanowią dość często przedmiot rozważań językoznawczych $\mathrm{w}$ rozmaitych kontekstach, to problematyka antywartości wydaje się niedostatecznie opracowana. Dlaczego zasługuje ona na refleksję? W odróżnieniu od wartości, na przykład prawdy, dobra, piękna, sprawiedliwości, godności, które, wedle reguły „chciałbym, dążę, zamierzam, warto, należy", mieszczą się częściej w zadanym i pożądanym niż rzeczywistym obszarze działań jednostki, można by rzec, w sferze projekcji, antywartości należą zdecydowanie do sfery empirii, sytuują się w obszarze codziennych doświadczeń. $Z$ tego też powodu, jakkolwiek niechciane i częstokroć odczuwane jako przykre, są one bliższe człowiekowi i częściej mu towarzyszą. Z niesprawiedliwością, kłamstwem, nienawiścią, lenistwem, nietolerancją, chorobą czy śmiercią pośrednio lub bezpośrednio zetknął się prawie każdy. Antywartości są rzeczywistością antropologiczną. 
Przedmiot niniejszej refleksji stanowi zło. Według prekursorki polskiej aksjolingwistyki Jadwigi Puzyniny zło jest centrum pojęciowym wartości transcendentnych (metafizycznych), które znajdują się na szczycie hierarchii wartości negatywnych ostatecznych, antywartości [Puzynina 1992: 40-41]. Jako nadrzędna negatywna wartość transcendentna zło stanowi węzłowy problem dociekań nauk antropologicznych, społecznych i humanistycznych. Jest ono nieustającym obiektem zainteresowania rozmaitych dyscyplin. Odwieczny problem filozoficzny zwerbalizowany w pytaniach unde malum? oraz quid sit malum? nurtuje i fascynuje nie tylko myślicieli (ontologia zła), ale również psychologów (zło jako cierpienie), kryminologów (zło jako przestępstwo), socjologów (zło społeczne, np. wojna, bezrobocie), medyków (zło jako choroba), teologów (zło metafizyczne, zło jako grzech, teodycea); jest również źródłem dociekań zwykłego człowieka, pozostając wymykającą się umysłowi zagadką. Schopenhauerowski pesymizm, znajdujący wyraz $w$ tezie, że świat w swoim porządku fizycznym i moralnym jest najgorszym ze wszystkich możliwych światów [Krąpiec 1962: 61], oraz Kantowska konstatacja „świat pogrąża się w złu" [Kant 2007: 39] zyskują współcześnie szczególnie aktualny wymiar, gdy zło $\mathrm{w}$ rozmaitych postaciach urasta do niespotykanych rozmiarów (by wspomnieć totalitaryzm, nacjonalizm, terroryzm, proliferację). Zgłębianie fenomenu zła staje się tym samym nie tylko nieprzerwanym wyzwaniem, ale koniecznością.

Co językoznawca może wnieść do toczącej się bezustannie interdyscyplinarnej dyskusji o istocie, źródłach i doświadczaniu zła? Pomocna w odpowiedzi na to pytanie może się okazać psycholingwistyka. Mając na względzie stwierdzony naukowo fakt, iż wszelkie pojęcia przechowywane w umyśle człowieka są ze swojej natury dynamicznymi strukturami powiązanymi wzajemnie w silnie zhierarchizowane układy, podatne i otwarte na przemiany pod wpływem bodźców i informacji płynących ze świata zewnętrznego, można przypuszczać, że również pojęcie zła funkcjonujące $w$ języku etnicznym ewoluuje i wykazuje tendencje do ulegania modyfikacji semantycznej. Przemiany pojęć, wyrażające się czy to w ubożeniu czy to wzbogacaniu ich spektrum znaczeniowego, mogą zachodzić w sposób trudno zauważalny dla kogoś, kto wiedzę na temat ich semantyki czerpie z zasobów systemowych języka, zwłaszcza rozmaitych jednojęzycznych słowników rejestrujących definicje normatywne pojęć, często statyczne, jednoaspektowe, charakteryzujące się wysokim stopniem uogólnienia, ograniczające się do obszaru denotacyjnego, pomijające sferę konotacyjną, która jest bardziej aktualna i w bardziej adekwatny sposób wyraża stosunek przeciętnego użytkownika języka do zastanej rzeczywistości. Jedną z metod pozwalających dotrzeć do aktualizacji pojęć, w tym interesującego mnie pojęcia zła, jest eksploracja świadomości językowej, definiowanej przez Jewgienija Tarasowa jako „całokształt pozio- 
mów świadomości, formowanych i uzewnętrznianych za pomocą środków językowych: słów, związków wyrazowych, zdań, tekstów i pól asocjacyjnych" [Тарасов 2000: 26]. Według założeń teoretycznych psycholingwistyki świadomość językowa łączy w sobie dwa krańcowo odmienne obszary: niematerialną tożsamość jednostki, wyrażającą się w jej świadomości, będącej niemierzalnym, nieuchwytnym fenomenem psychicznym, oraz język, widzialne i słyszalne zjawisko fizyczne. Penetracja świadomości językowej daje możliwość wglądu nie tylko w nieuchwytną zmysłowym poznaniem sferę całej gamy procesów psychicznych, ale szczególnie w sferę pojęć oraz ich wzajemnych ustrukturyzowanych powiązań, sferę pozazmysłowego postrzegania rzeczywistości, językowy obraz świata, pozwala zidentyfikować i ustalić tożsamość użytkownika języka, przede wszystkim zaś, na co wskazują badacze [m.in. Barlett 1932; Osgood, Sebeok 1965; Лурия, Виноградов 1971; Уфимцева 1998], jego tożsamość etnokulturową. Dość wcześnie, bo już w pierwszej połowie minionego wieku, wykazano, że systemy pojęć tworzą sieci werbalne [Chlewiński 1999], później także, że pozostają one pod silnym wpływem warunków życia społecznego, ekonomicznego oraz kultury etnicznej, w której jednostka zdobywa doświadczenie. Zmiany tych warunków pociągają za sobą strukturalną reorganizację sieci werbalnych i, co za tym idzie, redefiniowanie oraz rekonceptualizację pojęć. Wiedza w tym obszarze otwiera możliwość interesujących studiów interkulturowych, studiów porównawczych.

Uznanym i sprawdzonym narzędziem wykorzystywanym w eksploracji świadomości językowej jest psychofizjologiczne badanie czasowych związków międzywyrazowych, określane mianem testu asocjacji werbalnych. Tak zwane proste (w odróżnieniu od ciągłego) badanie skojarzeń słownych polega na tym, że ankietowany otrzymuje listę wyrazów hasłowych i zapisuje pierwsze słowo lub wyrażenie, które przychodzi mu na myśl, kojarzy się z wyrazem-hasłem. Materiał empiryczny analizowany w niniejszych rozważaniach odnośnie do zła wyekscerpowano z dwóch źródeł słownikowych, w których zawarte zostały wyniki testu swobodnych skojarzeń na 120 słów-bodźców, przeprowadzonego wspomnianą metodą. Są to Polski słownik asocjacyjny z suplementem [Gawarkiewicz, Pietrzyk, Rodziewicz 2008] oraz Craßянский ассоциативный словарь [Уфимцева, Черкасов, Караулов, Тарасов 2004]. Ваdania stanowiące podstawę opracowań leksykograficznych przeprowadzono na grupie 500 respondentów, studentów rozmaitych kierunków i specjalności w polskich oraz rosyjskich ośrodkach uniwersyteckich. Pierwotna lista wyrazów hasłowych została opracowana przez pracowników Instytutu Psycholingwistyki RAN, a następnie przetłumaczona i wykorzystana w eksperymencie polskojęzycznym. Dane do analizy referowanego pojęcia zaczerpnięte zostały z pierwszej części słowników, rejestrującej wyniki testu asocjacji werbalnych 
według porządku S-R, to jest od bodźca do reakcji. Jest to materiał językowy w postaci 316 reakcji na wyrazy hasłowe ZŁO i 3ЛO, 109 odpowiedzi polskojęzycznych i 207 skojarzeń rosyjskojęzycznych. Jego analiza zmierzać będzie do wytyczenia pól asocjacyjnych, charakteryzujących wybrane koncepty, oraz do uzyskania odpowiedzi na pytanie, w jaki sposób badani profilują zło, czyli co myślą, co wiedzą, jakie są ich wyobrażenia na ten temat, czy i jak dokonują ewaluacji tego pojęcia.

Jak zatem współcześni młodzi Polacy i Rosjanie rozumieją zło? Zarówno w polsko-, jak i rosyjskojęzycznym słowniku zdecydowana większość odpowiedzi skupiona wokół pojęcia zła (porównywalna również w ujęciu kwantytatywnym) werbalizowana jest przy pomocy pojęć przeciwstawnych - dobra i dobroci, por.: w języku polskim - dobro (150 reakcji - 30\% ogółu udzielonych odpowiedzi), brak dobra (1 reakcja - 0,2\%), nie dobro; w języku rosyjskim - добро (167 reakcji - 33,4\%), и добро (6 reakcji - 1,2\%), во имя добра (1 reakcja - 0,2\%), доброта (2 reakcje - 0,4\%), недостаток добра (1 reakcja - 0,2\%), противоположность добру (1 reakcja - 0,2\%). Odnosząc się do prowadzonych w badaniach skojarzeń analiz ilościowych i jakościowych ich struktury, można stwierdzić, iż obecność reakcji natury antonimicznej jest $\mathrm{w}$ wysokim stopniu przewidywalna - to jeden z czterech podstawowych typów reakcji słownych pozyskiwanych w testach skojarzeniowych obok synonimów i hiperonimów, uzupełnień i orzeczeń oraz ocen i skojarzeń związanych z doświadczeniem jednostki [Kurcz 1976: 192]. Jest to przejaw dualizmu ontycznego i dualizmu poznawczego, obecnych w myśleniu człowieka i percepcji rzeczywistości. Taki sposób myślenia znajduje odzwierciedlenie w refleksji filozoficznej, w której zło nader często rozpatrywane jest $\mathrm{w}$ ujęciu agatologicznym. Nie bez racji już w XIII wieku Akwinata pisał, że ,jeden z elementów przeciwstawnych poznaje się przez drugi, podobnie jak ciemność przez światło, dlatego też (poznanie) czym jest zło powinno się dokonać z (ujęcia) treści dobra" [cyt. za: Krąpiec 1962: 8]. Poświadczenie tej prawidłowości procesów poznawczych odnaleźć można również w zasobach systemowych obu języków, zwłaszcza w proverbiach, por. np.: w języku polskim - Nie ma tego złego, co by na dobre nie wyszło, Nie ma złego bez dobrego, Kto nie skosztowat złego, niegodzien dobrego, Kto nie zna złego, nie zna dobrego, Przejdzie złe, będzie dobre, Złe z domu, dobre w dom; w języku rosyjskim Ищущий добра на зло натыкается, Кто не способен на зло, тот не способен и на добро, Добро помнится долго, но зло еще дольше, Добро - изнанка зла, И добро и зло - в твоем сердие, Где добро, там и зло.

Dla badanych Polaków jednym z kluczowych dla konceptualizacji zła okazuje się odniesienie do dyskursu teologiczno-chrześcijańskiego, szczególnie teodycei - filozoficznej polemiki zmierzającej do wyjaśnienia pochodzenia i celowości zła w świecie stworzonym przez Boga uosabiającego absolutne dobro. W teodyceach Ojców Kościoła, ale także późniejszych, rozważany jest 
między innymi problem źródła zła naturalnego - grzechu pierworodnego, który z kolei w opinii polemistów mógł być konsekwencją zła proweniencji metafizycznej, pozazmysłowej - szatana, upadłego anioła, złego ducha, który dokonał zniszczenia doskonałego dzieła Stwórcy [Emberger 2013]. W świadomości językowej Rosjan ta wpisująca się w teodycejski kontekst część konceptualizacji nie znajduje aż tak wyraźnego potwierdzenia, por.: reakcje polskojęzyczne - diabet (40 reakcji - 8\%), szatan (17 reakcji - 3,4\%), grzech (6 reakcji - 1,2\%), w sumie $12,6 \%$ ogółu reakcji; reakcje rosyjskojęzyczne дьявол (8 reakcji - 1,6\%), бес (1 reakcja - 0,2\%), сатана ( 1 reakcja - 0,2\%), иерт (1 reakcja-0,2\%), ogółem 2,2\% pozyskanych odpowiedzi.

W materiale polskojęzycznym równie silnie usieciowiony jest związek zła z rozmaicie pojmowanymi aktami przemocy. W historii myśli filozoficznej ten rodzaj zła bywa określany mianem zła radykalnego (Kant), zła wpisanego w ludzką naturę, wynikającego z autonomii woli człowieka, z której jednakże ludzka słabość nie pozwala w pełni korzystać. Polacy identyfikują zło przede wszystkim z wojna (35 reakcji - 7\%), w dalszej kolejności z przemoca (8 reakcji - 1,6\%) i agresja (2 reakcje - 0,4\%), bójka (1 reakcja - 0,2\%), przestępstwem (4 reakcje - 0,8\%) i przestępczościa (1 reakcja-0,2\%), zbrodnia (1 reakcja-0,2\%), morderstwem (1 reakcja - 0,2\%) i zabójstwem (1 reakcja - 0,2\%) oraz z okrucieństwem (1 reakcja - 0,2\%) i gwattem (1 reakcja - 0,2\%), podczas gdy dla Rosjan zło w tym ujęciu to yбuйcmbo (3 reakcje - 0,6\%) i yбить (1 reakcja - 0,2\%) oraz жестокость (1 reakcja - 0,2\%). Akty agresji łamią zasady etycznego zachowania, hamują czy wręcz negują rozwój moralny jednostki, którego celem jest, ogólnie rzecz ujmując, dążenie do dobra, sprawiedliwości, tolerancji, dążenie do wartości. Przytoczone reakcje można więc ujmować również w kategorii szerszej, tożsamej z klasycznym rozumieniem zjawiska zła, mianowicie w kategorii malum morale [Leibniz 2001: 80], zła moralnego. Mieszczą się w niej również zwerbalizowane przez uczestników eksperymentu inne postawy i czyny stojące w sprzeczności z etyką, przede wszystkim nienawiść, por. np.: asocjaty polskojęzyczne - nienawiść (19 werbalizacji - 3,8\%), kłamstwo (3 werbalizacje - 0,6\%), wrogość (2 reakcje - 0,4\%), oszustwo (1 reakcja-0,2\%), pycha (1 reakcja - 0,2\%), pijaństwo (1 reakcja - 0,2\%), zaślepienie (1 reakcja - 0,2\%); asocjaty rosyjskojęzyсzne - ненависть (21 werbalizacji - 4,2\%), обман (3 werbalizacje $-0,6 \%)$, зависть (2 reakcje $-0,4 \%)$, коварство (1 reakcja -0,2\%), ложь (1 reakcja -0,2\%), несправедливость (1 reakcja-0,2\%), пить (1 reakcja-0,2\%), предательство (1 reakcja-0,2\%).

Utrwalone $\mathrm{w}$ świadomości językowej respondentów powyższe związki międzywyrazowe jednoznacznie kierują uwagę analizującego pole asocjacyjne na kryjący się za nimi antropologiczny element struktury znaczeniowej pojęcia zła. Zło ma w wyobrażeniu przedstawicieli ankietowanych zbiorowości jednoznacznie wymiar ludzki, wymiar dialogiczny. Malum morale przeja- 
wia się wyłącznie $\mathrm{w}$ relacjach inter- $\mathrm{i}$ intrapersonalnych, przy czym człowiek jest zarówno sprawcą zła, jak i doświadczającym zła, jego ofiarą. Fakt ten potwierdza szereg asocjatów wskazujących explicite na relację zło - człowiek, por. np.: skojarzenia w języku polskim - wróg (4 odpowiedzi - 0,8\%), nieprzyjaciel (2 odpowiedzi -0,4\%), bandzior (1 reakcja-0,2\%), człowiek (1 reakcja - 0,2\%), skin (1 reakcja - 0,2\%), złodziej (1 reakcja - 0,2\%); skojarzenia w języku rosyjskim - вpaz (5 odpowiedzi - 1\%), вpazu (2 odpowiedzi - 0,4\%), со стороны врага (1 reakcja - 0,2\%), человек (4 reakcje - 0,8\%), человечество (1 reakcja - 0,2\%), людское (2 reakcje - 0,4\%), люди (1 reakcja - 0,2\%), военный (1 reakcja-0,2\%), мое (1 reakcja -0,2\%), негодяй (1 reakcja-0,2\%), неприятель (1 reakcja - 0,2\%), плохой человек (1 reakcja - 0,2\%), mbое (1 reakcja $0,2 \%)$, ты (1 reakcja - 0,2\%). Pośrednio na człowieka jako czynnik sprawczy zła wskazują również reakcje rosyjskojęzyczne ujęzykowione słowami $m b o-$ рить (4 odpowiedzi - 0,8\%), намеренное (1 reakcja - 0,2\%), не делать (1 reakсја - 0,2\%), не причинить (1 reakcja - 0,2\%), причиненное (1 reakcja - 0,2\%) і причинить (1 reakcja - 0,2\%), сделать (1 reakcja - 0,2\%) oraz narzędzia zła: nóż (1 reakcja-0,2\%), wódka (1 reakcja-0,2\%), pistolet (1 reakcja - 0,2\%); деньги ( 2 reakcje $-0,4 \%)$, нож (1 reakcja $-0,2 \%$ ).

W znacznie mniejszym stopniu w świadomości językowej ankietowanych zaznacza się obecność malum physicum [Leibniz 2001: 80], zła fizycznego. Wyraża się ono $\mathrm{w}$ związku między referowanym pojęciem a skojarzeniami identyfikowanymi ze zjawiskami niezależnymi od woli i rozumu człowieka takimi, jak: w języku polskim - ból (5 reakcji - 1\%), cierpienie (4 reakcje - 0,8\%), śmierć (4 reakcje - 0,8\%), choroba (1 reakcja - 0,2\%); w języku rosyjskim - бoль (6 reakcji - 1,2\%), смерть (4 reakcje - 0,8\%), болезнь (1 reakcja - 0,2\%). Prawie całkowicie nieobecny jest $\mathrm{w}$ strukturach mentalnych respondentów drugi aspekt zła fizycznego uwarunkowanego sensu largo niedoskonałością świata, zła urzeczywistniającego się często na skutek zbiegu przypadkowych okoliczności, wypadków losowych. Znajduje on odzwierciedlenie jedynie w trzech jednostkowych reakcjach rosyjskojęzycznych - бедствие, огонъ і пожар.

Zło konceptualizowane jest w świadomości językowej badanych również jako doznanie uczuciowe. Będąc integralną częścią ludzkiego doświadczenia, poddawane jest ewaluacji emocjonalnej. Wartościowanie zła ukierunkowane jest jednoznacznie in minus, towarzyszą mu odczucia o charakterze repulsywnym, dyskomfort psychiczny, rzadziej dolegliwość fizyczna, co znajduje wyraz $\mathrm{w}$ odpowiedziach przedstawicieli obu ankietowanych społeczności, por. np.: asocjaty w języku polskim - strach (14 reakcji - 2,8\%), smutek (4 reakcje - 0,8\%), przykrość (3 reakcje - 0,6\%), gniew (2 reakcje - 0,4\%), płacz (2 reakcje $-0,4 \%)$, gorycz (1 reakcja - 0,2\%), niepokój (1 reakcja - 0,2\%), udręka (1 reakcja - 0,2\%), złość (1 reakcja - 0,2\%); asocjaty w języku rosyjskim - creзы (3 reakcje $-0,6 \%)$, злость (2 reakcje $-0,4 \%)$, гнев (1 reakcja - 0,2\%), горе 
(1 reakcja - 0,2\%), горечь (1 reakcja - 0,2\%), ненавижу (1 reakcja - 0,2\%), печаль ( 1 reakcja -0,2\%), печальное (1 reakcja - 0,2\%), раздражение (1 reakcja-0,2\%), $\operatorname{cmpax}(1$ reakcja $-0,2 \%)$.

W obszarze waluatywnym, obok reakcji ujęzykowionych w większości nazwami uczuć, sytuują się asocjaty obrazujące wartościowanie według prymarnych parametrów aksjologicznych, werbalizowane na ogół przy pomocy środków leksykalnych o wydźwięku jednoznacznie negatywnym, szczególnie silnie reprezentowanych $\mathrm{w}$ międzywyrazowych sieciach utrwalonych w świadomości respondentów rosyjskojęzycznych (blisko 10\% ogółu skojarzeń), por., np.: w języku polskim - nieprawidłowość (3 reakcje - 0,6\%), źle (3 reakcje $-0,6 \%$ ), coś niedobrego (2 reakcje $-0,4 \%$ ), nie lubić (1 reakcja - 0,2\%), niedobre (1 reakcja - 0,2\%); w języku rosyjskim - nлoxo (40 reakcji - 9\%), nлoхое (3 reakcje - 0,6\%), неприятность (1 reakcja - 0,2\%), нехорошо (1 reakcja - 0,2\%), плохое дело (1 reakcja - 0,2\%), хуже (1 reakcja - 0,2\%), это плохо (1 reakcja $-0,2 \%)$.

Ewaluacja implicite o zabarwieniu deprecjonującym dokonuje się po części również w obszarze atrybutywnym pola asocjacyjnego, w którym zło charakteryzowane jest $\mathrm{w}$ ujęciu ilościowym i jakościowym. Zło rejestrowane jest w leksykonie umysłowym badanych przede wszystkim jako zjawisko o wysokim stopniu nasilenia, niebezpieczne, podstępne, por. np.: skojarzenia polskojęzyczne - straszne (4 reakcje - 0,8\%), demoniczne (2 reakcje -0,4\%), duże (1 reakcja-0,2\%), okropieństwo (1 reakcja - 0,2\%); skojarzenia rosyjskojęzyczne - много (5 reakcji - 1\%), большое (3 reakcje - 0,6\%), опасность (2 reakcje $0,4 \%)$, велико ( 1 reakcja - 0,2\%), жестоко (1 reakcja - 0,2\%), жестокое (1 reakcja - 0,2\%), коварно (1 reakcja - 0,2\%), коварное (1 reakcja - 0,2\%), подло (1 reakcja-0,2\%), сейчас его много (1 reakcja - 0,2\%), ужасно (1 reakcja - 0,2\%).

W słowniku gromadzącym materiał rosyjskojęzyczny odnotowano również odpowiedzi odnośnie do trwałości w czasie i potencjalnego triumfu zła. Stosunek do problemu nieprzemijalności zła jest ambiwalentny, jakkolwiek przeważa przekonanie badanych, $w$ intuicyjnym nawiązaniu do leibnizjańskiej myśli o „samonaprawialności” świata [Leibniz 2001], że istnieje bliżej niesprecyzowana możliwość jego przezwyciężenia, por.: Вечно (2 reakcje $0,4 \%$ ), вечное ( 1 reakcja - 0,2\%), побеждает (2 reakcje - 0,4\%), вернется (1 reakcja-0,2\%), непобедимо (1 reakcja-0,2\%), непобедимое (1 reakcja-0,2\%), победит (1 reakcja - 0,2\%), есть всегда (1 reakcja - 0,2\%); исчезнет (2 reakcјe $-0,4 \%)$, победимо (2 reakcje - 0,4\%), не победит (1 reakcja - 0,2\%), невечно ( 1 reakcja - 0,2\%), повержено (1 reakcja - 0,2\%), проиграет (1 reakcja - 0,2\%), искореним (1 reakcja - 0,2\%), искоренимо (1 reakcja - 0,2\%), погибает (1 reakcja $-0,2 \%)$, yüdem (1 reakcja-0,2\%).

Niezależnie od perspektywy pokonania zła zarówno polscy, jak i rosyjscy uczestnicy eksperymentu dostrzegają związek zła z karą. Konieczność kara- 
nia zła ma na ogół charakter retrybutywny i sprowadza się do idei odwetu odpłaty złem za zło. W ujęcie penalne wpisują się następujące skojarzenia: w języku polskim - piekło (7 reakcji - 1,4\%), kara (4 reakcje - 0,8\%), więzienie (3 reakcje - 0,6\%); w języku rosyjskim - наказано (7 reakcji - 1,4\%), должно быть наказано (3 reakcje - 0,6\%), месть (3 reakcje - 0,6\%), наказуемо (3 reakcje $-0,6 \%)$, ад (2 reakcje $-0,4 \%)$, будет наказано (1 reakcja - 0,2\%), наказание (1 reakcja - 0,2\%), наказать (1 reakcja - 0,2\%).

Niezaprzeczalny jest fakt obecności zła w rzeczywistości doświadczanej przez badaną młodzież. Przekonanie to znajduje wyraz dwukrotnie częściej w rosyjskojęzycznym źródle leksykograficznym. Zło jest wszechobecne, jest immanentną własnością otaczającego świata, por.: odpowiedzi w języku polskim - świat (2 skojarzenia - 0,4\%), codzienność (1 skojarzenie - 0,2\%), czai się (1 skojarzenie - 0,2\%), drą̇zy (1 skojarzenie - 0,2\%), rzeczywistość (1 skojarzenie $-0,2 \%)$, szerzy się (1 skojarzenie $-0,2 \%$ ), wokót mnie (1 skojarzenie $-0,2 \%$ ), wszechobecne (1 skojarzenie - $0,2 \%$ ), wszędzie (1 skojarzenie $-0,2 \%$ ), za rogiem (1 skojarzenie - 0,2\%); odpowiedzi w języku rosyjskim - ecmı (8 skojarzeń $1,6 \%)$, везде (4 skojarzenia - 0,9\%), существует (2 skojarzenia - 0,4\%), в мире (1 skojarzenie - 0,2\%), а что делать (1 skojarzenie - 0,2\%), если бы его не было на земле (1 skojarzenie - 0,2\%), есть в каждом (1 skojarzenie - 0,2\%), мир ( 1 skojarzenie $-0,2 \%)$, на земле (1 skojarzenie - $0,2 \%$ ), nравит (1 skojarzenie $0,2 \%$ ), nрuсymcmbyem (1 skojarzenie $-0,2 \%$ ).

W szeregu skojarzeń o relatywnie niskim stopniu powszechności wyboru realizuje się konceptualizacja systemowa odpowiadająca statusowi normatywnemu, to jest odzwierciedlająca zawartość definicji słownikowych, por., np.: asocjaty w języku polskim - krzywda (10 reakcji - 2\%), nieszczęście (9 reakcji - 1,8\%); asocjaty w języku rosyjskim - несчастье (6 reakcji - 1,2\%), вред (6 reakcji - 1,2\%), беда (2 reakcje $-0,4 \%)$, ярость ( 2 reakcje $-0,4 \%)$.

Ostatnia spójna logicznie grupa odnotowanych przez słowniki asocjacyjne odpowiedzi to reakcje skupione w obszarze symboliczno-kulturowym. Wyraźne sieci werbalne $\mathrm{w}$ tym aspekcie tworzą związki bazowego pojęcia z czernią oraz konotacyjnymi szeregami tejże barwy i, szerzej, koloru ciemnego, por. np.: czerń (22 reakcje - 4,4\%), ciemność (3 reakcje - 0,6\%), czarny (3 reakcje $-0,6 \%)$, czarny charakter (1 reakcja - 0,2\%), ciemno (1 reakcja - 0,2\%), czarne (1 reakcja-0,2\%), czarno (1 reakcja - 0,2\%), черное (11 reakcji - 2,2\%), черныи (10 reakcji - 2\%), темнота (2 reakcje - 0,4\%), мрак (1 reakcja - 0,2\%), темное (1 reakcja - 0,2\%), черный извет (1 reakcja-0,2\%). Nie są to skojarzenia bezpodstawne, gdyż potwierdzają je konotacje systemowe będące efektem uprzedniego profilowania kulturowego obecne w zasobach frazeologicznych języka polskiego i rosyjskiego. Metaforyczne użycia czerni i barwy ciemnej są komponentem jednostek ze znaczeniem niepomyślnego, złego czasu, zdarzenia, ogólnie negatywnej charakterystyki, por. np.: czarny charakter, czarna 
rozpacz, czarna godzina, czarna lista, ciemny jak tabaka w rogu w języku polskim; черный день, черная душа, черное дело, черная зависть, темное изарство w је̨zуku rosyjskim.

W omawianej sferze umieścić można również odnoszące się do kulturowych artefaktów jednostkowe skojarzenia rosyjskojęzyczne takie, jak: волшебник, дракон, колдун, Кощей Бессмертный, монстры, нечисть.

Pozostałe asocjaty, znacznie rozproszone pod względem semantyki i logiki, odnieść należy do katalogu skojarzeń rejestrującego indywidualnie doświadczane, przetwarzane i aktualizowane w leksykonie umysłowym użytkowników obu języków schematy poznania i wiedzy o złu.

Reasumując, konceptualizowanie zła przez przedstawicieli obu zbiorowości językowych odbywa się w kilku wyraźnie rozpoznawalnych obszarach. Zło interpretowane jest przede wszystkim na płaszczyźnie agatologicznej, w dalszej kolejności, zwłaszcza przez Polaków, w mniejszym stopniu przez Rosjan, w kategorii zła moralnego. Zło natury fizycznej, choć obecne w świadomości językowej badanych, nie stanowi istotnego elementu profilu asocjacyjnego. Zło jako wynik relacji międzyludzkich aktualizuje się w wyższym stopniu w skojarzeniach rosyjskojęzycznych. Z kolei asocjaty polskojęzyczne $\mathrm{w}$ większej mierze poświadczają emocjonalny stosunek respondentów do zła.

Ewaluacja zła w kolektywnej świadomości zarówno Polaków, jak i Rosjan ma charakter zdecydowanie dezaprobatywny. Ankietowani są również zgodni w kwestii obecności zła w zastanych realiach oraz konieczności wymierzania kary. Bliski pod względem frekwencji odpowiedzi i koherencji znaczeniowej jest także profil symboliczny zła.

W rosyjskojęzycznym profilu asocjacyjnym ścierają się elementy treściowe ujawniające wzajemną sprzeczność $\mathrm{w}$ odniesieniu do możliwości przezwyciężenia zła z nieznaczną przewagą tych, które wytyczają pozytywną perspektywę walki ze złem.

Proponowane przez badanych interpretacje zła wykraczają poza normatywne ujęcia pojęcia, konstytuując ciekawe i wzbogacone semantycznie profile analizowanej jednostki leksykalnej, których źródłem są po części własne doświadczenia, po części potoczna wiedza kształtowana przez rzeczywistość społeczną i kulturalną, dając jednocześnie wyraz istnieniu niedostatecznie znanych lub pomijanych sposobów kategoryzacji zła.

W zakończeniu przytoczę słowa nestorki polskiej filozofii Barbary Skargi: „Pytanie o zło nie ma tylko intelektualnego, filozoficznego charakteru, ono samo ma przede wszystkim wymiar moralny, gdyż jest wyrazem sprzeciwu wobec zła i pragnienia zwycięskiej z nim walki. Dlatego zadawane jest od wieków [...] i powinno być zadawane mimo braku satysfakcjonujących odpowiedzi" [Skarga 1993: 42]. 


\section{Bibliografia}

Лурия А. Р., Виноградов О. С. 1971. Объективное исследование динамики семантических систем. Семантическая структура слова, Москва: Наука.

Тарасов Е. Ф. 2000. Актуальные проблемы анализа языкового сознания, [w:] Н. В. Уфимцева (red.). 2000. Языковое сознание и образ мира, Москва: Институт языкознания PAH, s. 24-32.

Уфимцева Н. В. 1998. Этнический характер, образ себя и языковое сознание русских, [w:] Н. В. Уфимцева (red.), Языковое сознание: формирование и функиионирование, Москва: Институт языкознания РАН, s. 135-171.

Уфимцева Н. В., Черкасова Г. А., Караулов Ю. Н., Тарасов Е. Ф. 2004. Славянский ассоцииативный словарь: русский, белорусский, болгарский, украинский, Москва: Институт языкознания РАН.

Barlett F. C. 1932. Remembering: A study in experimental and social psychology, Cambridge: Cambridge University Press.

Chlewiński Z. 1999. Umyst. Dynamiczna organizacja pojęć. Analiza psychologiczna, Warszawa: Wydawnictwo Naukowe PWN.

Emberger G. 2013. Teologiczne i naukowe wyjaśnienia pochodzenia i celu zła naturalnego, „Filozoficzne Aspekty Genezy", t. 10, źródło elektroniczne: http://www.nauka-a-religia. uz.zgora.pl/images/ FAG/2013.t.10/art.09.pdf (dostęp 15.08.2017).

Gawarkiewicz R., Pietrzyk I., Rodziewicz B. 2008. Polski stownik asocjacyjny z suplementem, Szczecin: Print Group.

Kant I. 2007. Religia w obrębie samego rozumu, tłum. A. Bobko, Kraków: Wydawnictwo Homini.

Krąpiec M. 1962. Dlaczego zło? Rozważania filozoficzne, Kraków: Znak.

Kurcz I. 1976. Psycholingwistyka. Przegląd problemów badawczych, Warszawa: PWN.

Leibniz G. W. 2001. Teodycea. O dobroci Boga, wolności człowieka i pochodzeniu zła, tłum. M. Frankiewicz, Warszawa: PWN.

Osgood C. E., Sebeok T. A. 1965. Psycholinguistics. A Survey of Theory and Research Problems, Bloomington: Indiana University Press.

Puzynina J. 1992. Języ wartości, Warszawa: PWN.

Skarga B. 1993. Pytać o zło, „Znak”, nr 454 (3), s. 4-12. 